\title{
Pulmonary Nodule-associated Cat Scratch Disease in an Immunocompromised Patient
}

\author{
Bağışıklığı Baskılanmış Hastada Kedi Tırmığına Bağlı Pulmoner Nodul
}

Levent Özdemir' ${ }^{1}$ Burcu Özdemir², Mehtap Şencan ${ }^{3}$, Suat Durkaya ${ }^{4}$, Ayşegül Kaynar ${ }^{5}$, Zulal Özbolat ${ }^{1}$, Sema Çalışkan², Ali Ersoy ${ }^{6}$

\section{Abstract}

Cat-scratch disease (CSD) is an infectious disease presenting with chronic inflammation of lymph nodes that drain the portal of entry of the causative organism in immunocompetent persons. It may also manifest as encephalitis, neuroretinitis, granulomatous conjunctivitis, hepatosplenic involvement, or pneumonia and thrombocytopenic purpura in immunocompromised patients. A 50-year-old, previously healthy woman was evaluated for symptoms of cough, fever, and arthralgia. She had history of surgery for hydatid cyst (liver) 4 years earlier and 1 year of Deltacortril use for rheumatoid arthritis. Nodular formations were observed in the right anterior upper lobe, right middle lobe, and right inferior posterobasal lobe on chest tomography image. Laboratory analysis revealed no abnormal findings except leukocytosis. Aerobic culture and EZN staining of sputum were negative. The patient underwent diagnostic video-assisted thoracoscopic surgery. Pathological results were reported as granulomatous disease, excluding tuberculosis and sarcoidosis, and indicating likely CSD, presenting with polymorphonuclear leukocytes in the granulomas.

Key words: Pulmonary nodule, Cat Scratch Disease, immunocompromised.

\section{Özet}

Kedi tırmığı hastalığı, bağışıklık sistemi normal kişilerde, giriş yerinin drene olduğu lenf dügümlerinde kronik inflamasyonla seyreden bir infeksiyondur. Bağışıklık sistem baskılanmış olan hastalarda ensefalit, nöroretinit, granülomatöz konjunktivit, hepatosplenik tutulum, pnömoni ve trombositopenik purpura gibi klinik tablolar şeklinde de ortaya çıkabilir. Elli yaşında kadın hasta öksürük, ateş, eklem ağrısı nedeni ile değerlendirildi. Özgeçmişinde dört yıl önce karaciğer kist hidatiği nedeni ile operasyon ve romatoid artrit nedeni ile bir yıldır deltakortil kullanımı mevcuttu. Toraks tomografisinde sağ alt lob superiyor ve üst lobta nodul saptandı. Laboratuvar incelemesinde lökositoz dışında anormallik saptanmadı. Balgam aerob kültür ve ARB incelemesi negatif olarak saptandı. Hastaya tanısal VATS uygulandı. Patoloji sonucu granülomlar içinde polimorf nüveli lokositler, tbc ve sarkoidoz dışı granülomatöz hastalık ön planda kedi tırmığı hastalığı olarak raporlandı.

Anahtar Sözcükler: Pulmoner nodul, Kedi tırmığı, bağışıklık baskılanmış.
'Department of Chest Diseases, Dörtyol State Hospital, Hatay,

\section{Turkey}

${ }^{2}$ Department of Chest Diseases, ìskenderun State Hospital, Hatay, Turkey

${ }^{3}$ Department of Infection Diseases, Dörtyol State Hospital, Hatay, Turkey

${ }^{4}$ Department of Thorasic Surgey, İskenderun State Hospital, Hatay, Turkey

${ }^{5}$ Department of Pathology, İskenderun State Hospital, Hatay, Turkey

${ }^{6}$ Department of Chest Diseases, Antakya State Hospital, Hatay, Turkey
'Dörtyol Devlet Hastanesi, Göğüs Hastalıkları Kliniği, Hatay ${ }^{2}$ iskenderun Devlet Hastanesi, Göğüs Hastalıkları Kliniği, Hatay

${ }^{3}$ Dörtyol Devlet Hastanesi, İnfeksiyon Hastalıkları Kliniği,

Hatay

${ }^{4}$ İskenderun Devlet Hastanesi Göğüs Cerrahisi Kliniği, Hatay

${ }^{5}$ Iskenderun Devlet Hastanesi, Patoloii Bölümü, Hatay

${ }^{6}$ Antakya Devlet Hastanesi, Gögüus Hastalıkları Kliniği, Hatay

Submitted (Başvuru tarihi): 13.08.2016 Accepted (Kabul tarihi): 12.12.2016

Correspondence (iletişim): Levent Özdemir, Department of Chest Diseases, Dörtyol State Hospital, Hatay, Turkey e-mail: levent2408@mynet.com 
Cat-scratch disease (CSD) is an infectious illness caused by Gram-negative rod Bartonella henselae and accompanied by chronic inflammation, including frequently slowly progressive and sometimes chronic form of regional lymphadenitis near the wound site (1). Disease can occur with wide spectrum of presentation, including osteomyelitis, encephalitis, neuroretinitis, granulomatous conjunctivitis, hepatosplenic micro abscesses, and renal abscesses in immunocompromised patients (2). Pulmonary manifestations are rare. Usual pulmonary manifestation is pleural effusion and pneumonia in immunocompromised host. Pulmonary nodules are rarely seen in patients with bacillary angiomatosis $(3,4)$.

In this article, patient presenting with pulmonary nodules who was under immunosuppressive medication and diagnosed with CSD via video-assisted thoracoscopic surgery (VATS) is described.

\section{CASE}

A 50-year-old, previously healthy woman presented with 8-day history of fever $\left(38-40^{\circ} \mathrm{C}\right)$, non-productive cough, and arthralgia. She had history of surgery for hydatid cyst (liver) 4 years earlier and 1 year of prednisone use (initial dose: $20 \mathrm{mg} / \mathrm{d}$, maintenance dose: $5 \mathrm{mg} / \mathrm{d}$ ) for rheumatoid arthritis. On physical examination, she was febrile $\left(38.7^{\circ} \mathrm{C}\right)$; tachycardic, with heart rate of $108 \mathrm{bpm}$; and respiratory rate of 22 breaths per minute. Bilateral rhonchi during expirium were present on chest auscultation. No pathological laboratory findings except leukocytosis $\left(14,000 / \mathrm{mm}^{3}\right.$; neutrophil count: $\left.10,900 / \mathrm{mm}^{3}\right)$ and elevated C-reactive protein level of $58 \mathrm{mg} / \mathrm{dL}$ were found. Serum serology for HIV was negative. Both sputum culture and aerobic blood culture revealed negative results. Ziehl-Neelsen staining of sputum was negative for acidfast bacilli. Chest computed tomography (CT) (Figure la and b) revealed nodular formations surrounded by ground-glass opacities in the right anterior upper lobe, right middle lobe, and right inferior posterobasal lobe. Ampicillin/sulbactam 4x1.5 gr/d, clarithromycin 2x500 $\mathrm{mg} / \mathrm{d}$ were initiated for non-specific treatment of nodular formations. As radiographical chest findings did not regress and diagnosis could not be made from culture results, diagnostic VATS was performed for differential diagnosis of sarcoidosis, tuberculosis, rheumatoid nodule, and hydatid cyst. Histopathological examination revealed polymorphonuclear leukocytes in the granulomas (Figure 2), indicating granulomatous disease, excluding tuberculosis and sarcoidosis, and suggesting CSD. After the patient was questioned again regarding her medical history, it was determined that 17 cats lived in her house and that she was occasionally clawed by them. The patient received doxycycline $200 \mathrm{mg} / \mathrm{d}$ for 4 weeks after VATS based on histopathological findings. After treatment, the patient was discharged from the hospital without complication. Written consent to publication was obtained from the patient at discharge.

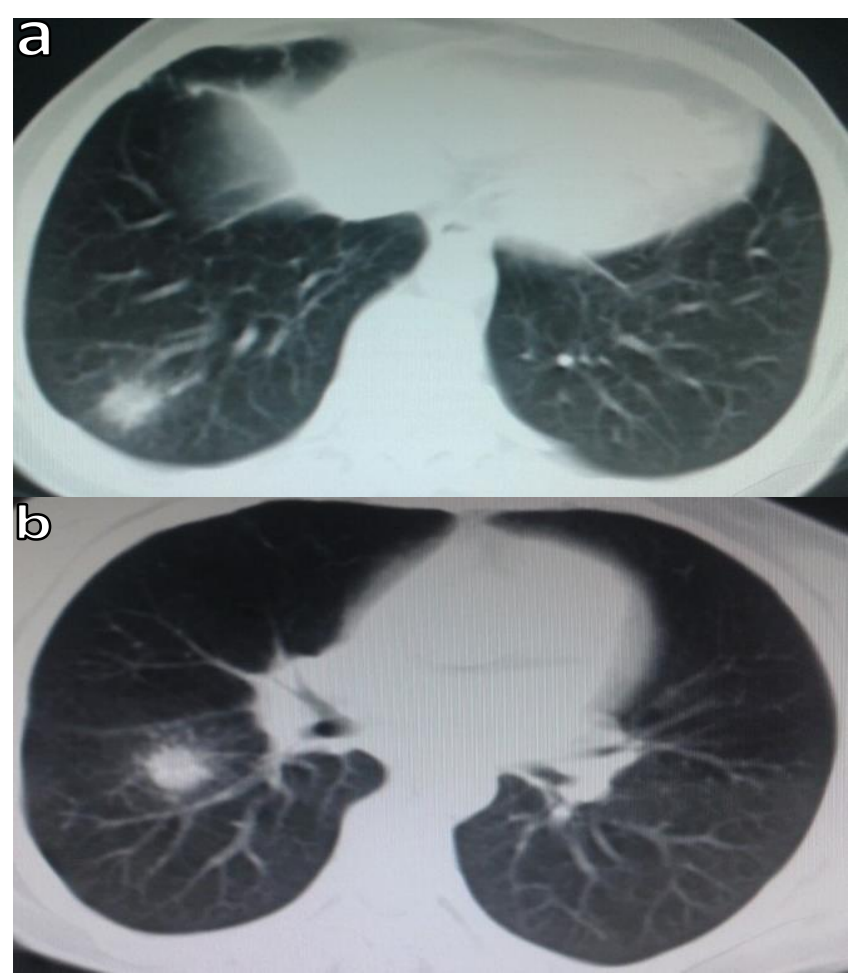

Figure 1a and b: Chest computed tomography revealed nodular formations surrounded by ground-glass opacities in the right anterior upper lobe, right middle lobe, and right inferior posterobasal lobe

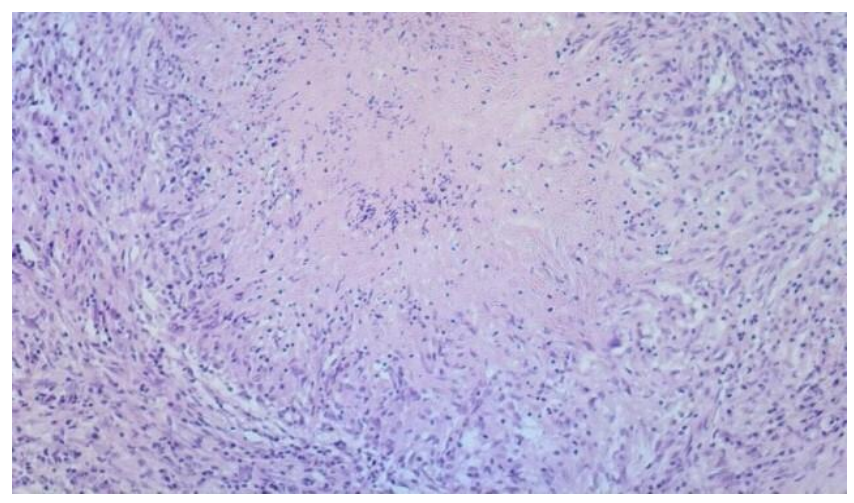

Figure 2: Histopathological examination demonstrated polymorphonuclear leukocytes in the granulomas

\section{DISCUSSION}

Despite many published articles on CSD with systemic dissemination, there have been only a few cases presenting with pulmonary nodules in immunocompromised patients in literature (3-6). Our patient was immunosup- 
pressed due to steroid therapy for rheumatoid arthritis and is a rare case of CSD presenting as lung nodules.

CSD exists in 2 forms: typical and atypical. In typical form, an initial skin lesion like non-painful, erythematous papule or pustule of 2 to $10 \mathrm{~mm}$ in diameter develops within 3 to 12 days at the site of scratch or bite, and often heals within 2 to 4 weeks without scarring. Subsequent development of regional lymphadenitis is most important clinical manifestation. Symptoms of low-grade fever, chill, weakness, anorexia, nausea, and headache may be present. In immunocompetent patients, CSD heals spontaneously in 2 to 5 months, and only rarely with scarring. However, disseminated lymphadenitis and fatal clinical outcomes may occur in immunocompromised patients, including those with AIDS, malignancy, or using immunosuppressive medication. In recent years, atypical form of CSD was reported in $10 \%$ to $25 \%$ of patients who had contact with the etiological agent. This form can present with high-grade fever, Parinaud's oculoglandular syndrome (5-6\%), neuroretinitis, endocarditis, encephalitis, arthralgia, arthritis, synovitis, osteomyelitis (0-3\%), pneumonia $(0-2 \%)$, or granulomatous hepatitis. Whereas our patient, who had regular contact with cats, manifested with clinical findings of fever, cough, and arthralgia, no regional lymphadenitis was observed on physical examination (7).

Serological tests are accepted as criterion standard in diagnosis of CSD. Initiation of humoral immune response begins before or simultaneously with onset of symptoms; therefore, estimation of single high titer of $\lg M$ and $\lg G$ antibodies by indirect fluorescent antibody or enzyme immunoassay is thought to be sufficient for diagnosis. Value of other diagnostic tests, including polymerase chain reaction and bacterial culture, is limited (8). Serological tests are not routinely used in our country for diagnosis of CSD (9).

Typical findings are estimated from histopathological examination of involved regional lymphadenitis. These findings include lymphoid hyperplasia accompanied by arteriolar proliferation initially, and subsequent regions of necrotizing granuloma involving histiocytes and polymorphonuclear leukocytes (10). Diagnosis of our case was made via clinical history and histopathological demonstration of polymorphonuclear leukocytes in the granulomas.

CSD restricts itself. Antibiotherapy is generally not necessary except in disseminated CSD (1 1). Disseminated CSD is more frequent in immunocompromised patients. Longterm antibiotic therapy is required to reduce mortality and morbidity in immunocompromised patients with atypical clinical course (12). Azithromycin, clarithromycin, doxycycline, trimethoprim-sulfamethoxazole, rifampicin, ciprofloxacin, and gentamycin are used in treatment of CSD (13). We used ampicillin-sulbactam and clarithromycin in initial treatment. There was no response to that therapy; however after pathological diagnosis, doxycycline was administered for 4 weeks due to immunodeficiency.

As a conclusion, clinicians should be aware that CSD may manifest on occasion as pulmonary nodule in immunocompromised patients.

\section{CONFLICTS OF INTEREST}

None declared.

\section{AUTHOR CONTRIBUTIONS}

Concept - L.Ö., B.Ö., M.S., S.D., A.K., Z.Ö., S.Ç., A.E.; Planning and Design - L.Ö., B.Ö., M.S.., S.D., A.K., Z.Ö., S.Ç., A.E.; Supervision - L.Ö., B.Ö., M.Ş., S.D., A.K., Z.Ö., S.Ç., A.E.; Funding - L.Ö., B.Ö.; Materials - L.Ö., B.Ö.; Data Collection and/or Processing - L.Ö., B.Ö.; Analysis and/or Interpretation - L.Ö., B.Ö.; Literature Review - L.Ö., B.Ö.; Writing - L.Ö., B.Ö., M.S..; Critical Review - L.Ö.

\section{YAZAR KATKILARI}

Fikir - L.Ö., B.Ö., M.S.., S.D., A.K., Z.Ö., S.Ç., A.E.; Tasarım ve Dizayn - L.Ö., B.Ö., M.Ş., S.D., A.K., Z.Ö., S.Ç., A.E.; Denetleme - L.Ö., B.Ö., M.Ş., S.D., A.K., Z.Ö., S.Ç., A.E.; Kaynaklar - L.Ö., B.Ö.; Malzemeler L.Ö., B.Ö.; Veri Toplama ve/veya İşleme - L.Ö., B.Ö.; Analiz ve/veya Yorum - L.Ö., B.Ö.; Literatür Taraması L.Ö., B.Ö.; Yazıyı Yazan - L.Ö., B.Ö., M.Ş.; Eleştirel Inceleme - L.Ö.

\section{REFERENCES}

1. Centers for Disease Control and Prevention (CDC). Catscratch disease in children-Texas, September 2000August 2001. MMWR Morb Mortal Wkly Rep 2002; $51: 212-4$.

2. Maguina C, Gotuzzo E. Bartonellosis. New and old. Infect Dis Clin North Am 2000; 14:1-22. [CrossRef]

3. Dutta A, Schwarzwald HL, Edwards MS. Disseminated bartonellosis presenting as neuroretinitis in a young adult with human immunodeficiency virus infection. Pediatr Infect Dis J. 2010; 29:675-7. [CrossRef]

4. Moore EH, Russell LA, Klein JS, White CS, McGuinness $G$, Davis $L G$, et al. Bacillary angiomatosis in patients with 
AIDS: multiorgan imaging findings. Radiology 1995; 197:67-72. [CrossRef]

5. Burrowesn P, Goodman p. Multiple pulmonary nodules as a manifestation of cat-scratch disease. Can Assoc Radiol J 1995; 46:48-50.

6. Bandyopadhyay A, Burrage LC, Gonzalez BE. Pulmonary nodules in an immunocompetent child with cat scratch disease. Pediatr Infect Dis J 2013; 32:1390-2. [CrossRef]

7. Celebi B. Bortanella Henselae and its infections. Mikobiyol Bül 2008; 42:163-175.

8. Sander A, Berner R, Ruess M. Serodiagnosis of cat scratch disease; response to Bartonella henselae in children and a review of diagnostic methods. Eur J Clin Microbiol Infect Dis $2001 ; 20: 392-401$. [CrossRef]
9. Doğanay $M, Y_{ı} l d ı z O$. Deri ve derialtı dokusunun bakteriyel enfeksiyonları. In: Wilke Topcu A, Soyletir G, Doğanay M (eds). Enfeksiyon Hastalıkları ve Mikrobiyolojisi. 3. Baskı, İstanbul: Nobel Tıp Kitapevleri, 2008:1269-82.

10. Eroğlu C, Çandır N, Dervişoğlu A, Kefeli M. Kedi Tırmığı Hastalığı Olgusu. Mikobiyol Bül 2007: 41 603-6.

11. Margileth AM. Antibiotic therapy for cat-scratch disease: clinical study for therapeutic outcome in 268 patients and a review of the literature. Pediatr Infect Dis J 1992; 11:474-8. [CrossRef]

12. Spach DH, Koehler JE. Bartonella-associated infections. Infect Dis Clin North Am 1998; 12:137-55. [CrossRef]

13. Batts S, Demers DM. Spectrum and treatment of catscratch disease. Pediatr Infect Dis J 2004; 23:1161-2. 